\title{
Removal of Chromium from a Contaminated Soil Using Oxalic Acid, Citric Acid, and Hydrochloric Acid: Dynamics, Mechanisms, and Concomitant Removal of Non-Targeted Metals
}

\author{
Yuhuan Sun ${ }^{1}$, Feng Guan ${ }^{1,2}$, Weiwei Yang ${ }^{1}$ and Fayuan Wang ${ }^{1,3, *(\mathbb{D})}$ \\ 1 College of Environment and Safety Engineering, Qingdao University of Science and Technology, \\ Qingdao 266042, China \\ 2 Yantai Institute of Coastal Zone Research, Chinese Academy of Sciences, Yantai 264003, China \\ 3 Key Laboratory of Soil Resources and Environment in Qianbei of Guizhou Province, \\ Zunyi Normal University, Zunyi 563002, China \\ * Correspondence: wangfayuan@qust.edu.cn; Tel.: +86-532-8402-2617
}

Received: 20 June 2019; Accepted: 1 August 2019; Published: 2 August 2019

\begin{abstract}
Soil leaching is an effective remediation technique using agents to leach the target pollutants from the soil. However, the dynamics and mechanisms for leaching of $\mathrm{Cr}$ and other non-pollutant metals from Cr-contaminated soils are not yet well understood. Here, column leaching experiments were conducted to determine the effect of hydrochloric acid $(\mathrm{HCl})$, citric acid $(\mathrm{CA})$, and oxalic acid (OX) on the leaching of $\mathrm{Cr}$, as well as of $\mathrm{Ca}, \mathrm{Mg}$, $\mathrm{Fe}$, and $\mathrm{Mn}$, from a soil contaminated by a $\mathrm{Cr}$ slag heap. Acid leaching decreased soil $\mathrm{pH}$ and enhanced the mobility of all the surveyed metals. Leaching dynamics varied with both metals and acids. OX had the highest removal rates for $\mathrm{Cr}, \mathrm{Fe}, \mathrm{Mn}$, and $\mathrm{Mg}$, but had the poorest ability to leach $\mathrm{Ca}$. $\mathrm{HCl}$ leached the largest amount of $\mathrm{Ca}$, while $\mathrm{CA}$ leached similar amounts of $\mathrm{Mg}$ and $\mathrm{Mn}$ to $\mathrm{OX}$, and similar amounts of $\mathrm{Fe}$ and $\mathrm{Cr}$ to $\mathrm{HCl}$. $\mathrm{Cr}$ in the leachates was correlated with $\mathrm{Ca}, \mathrm{Mg}$, Fe, and $\mathrm{Mn}$. Cr mainly interacted with soil mineral components and showed a punctate distribution in soil particles. The X-ray diffraction (XRD), scanning electron microscopy with energy-dispersive X-ray spectroscopy (SEM-EDS), and X-ray photoelectron spectroscopy (XPS) analyses showed soil mineralogical and morphological properties were differently altered after leaching by different acids. Complexation of $\mathrm{Cr}(\mathrm{III})$, competitive desorption, and reduction of $\mathrm{Cr}(\mathrm{VI})$ make significant contribution to $\mathrm{Cr}$ leaching by organic acids. In conclusion, $\mathrm{OX}$ can be applied in leaching remediation of $\mathrm{Cr}$-contaminated soil, but the concomitant removal of other non-targeted metals should be taken into account because of the loss of soil minerals and fertility.
\end{abstract}

Keywords: chemical leaching; soil washing; column experiment; chromium; soil remediation

\section{Introduction}

Chromium ( $\mathrm{Cr}$ ) and its compounds have various applications in industrial processes, such as alloy production, electroplating, wood preservation, leather processing, development of pigments, printing and dyeing, and catalysis [1]. Like many other transition metal elements, $\mathrm{Cr}$ is essential to humans at low concentrations but toxic at higher concentrations, and thus considered a potential contaminant in soil and groundwater [2]. Cr can enter the environment by human activities (such as mining and plating) and several natural processes (such as weathering and biochemical reactions), and can subsequently cause environmental pollution [1,3,4], posing potential environmental risks. Thus, the efforts should be undertaken on effective remediation for Cr-contaminated sites. 
Soil leaching (or washing) is a widely used technique for soil remediation, which uses agents, such as inorganic eluent, chelation agents, and surfactant, to leach the target pollutants from the soil [5]. Acids are commonly used as eluents, because they can dissolve insoluble compounds such as carbonates and oxides, and disassociate metals from soil surfaces, thus enhancing their extractability and removal from soil [6,7]. Different acids have been applied in soil leaching, including inorganic acids such as hydrochloric acid $(\mathrm{HCl}), \mathrm{H}_{2} \mathrm{SO}_{4}, \mathrm{HNO}_{3}, \mathrm{H}_{3} \mathrm{PO}_{4}$, and $\mathrm{H}_{2} \mathrm{SiF}_{6}$, and organic acids such as formic acid, acetic acid, oxalic acid (OX), citric acid (CA), tartaric acid, and polyglutamic acid [8,9]. The metal removal efficiency not only depends on acids and metals contamination characteristics, but also varies with soil physicochemical properties such as soil $\mathrm{pH}$, texture, cation exchange capacity (CEC), and organic matter (OM) characteristics [8]. Therefore, more case studies are needed to enlarge the applicability of acid leaching.

Since acids are generally non-selective, they can leach out not only the pollutants, but also other elements including essential nutrients for organisms, inevitably causing soil matrix dissolution and poor soil structure, and the decrease in soil $\mathrm{pH}$ and fertility. Evidently, an ideal extractant should be environment-friendly, and can remove pollutants as much as possible, but remove non-pollutant elements as little as possible. During the leaching process of $\mathrm{Cr}$ and $\mathrm{Ni}$ using ethylenediaminetetraacetic acid (EDTA) and CA, other elements such as $\mathrm{Ca}, \mathrm{Fe}, \mathrm{Mg}, \mathrm{Al}, \mathrm{Mn}$, and $\mathrm{Zn}$ were also dissolved [10]. In another study, CA and tartarate (TA) were found as effective as EDTA and diethylenetriaminepentaacetic acid (DTPA) to extract pollutants $(\mathrm{Cd}, \mathrm{Cu}, \mathrm{Pb}$, and $\mathrm{Zn})$ from two contaminated soils, but they removed $80 \%$ less soil macronutrients ( $\mathrm{Fe}, \mathrm{Ca}$, and $\mathrm{Mg}$ ) and improved soil structure [11]. Thus, different agents may have various impacts on soil characteristics. However, the remediation mechanisms of target pollutant and concomitant removal of non-targeted metals during the remediation process are not yet well recognized.

Among the commonly used leaching agents, $\mathrm{HCl}$ could effectively dissolve minerals and transport metals and complexes in soil [6]. Organic acids such as CA and OX are considered biodegradable and environment-friendly low molecular weight organic acids $[10,12,13]$, which may exert less adverse influences on soil quality. Differently to $\mathrm{HCl}$, organic acids $\mathrm{CA}$ and $\mathrm{OX}$ can act as reducers and chelates of toxic metals, such as Cr [14]. Inorganic and organic acids may have different removal mechanisms during $\mathrm{Cr}$ leaching, and concomitant effects on leaching of non-targeted elements. Here, for the first time, the remediation effects and mechanisms of $\mathrm{HCl}, \mathrm{CA}$, and $\mathrm{OX}$ on a $\mathrm{Cr}$-polluted soil were compared using column leaching experiment. Our aims are (1) to compare the dynamics of $\mathrm{Cr}$ concentrations in the soil leachates with different acids; (2) to test the removal of non-targeted metals by the acids; and (3) to elucidate the mechanisms of $\mathrm{Cr}$ leaching via investigating the mineralogical and morphological properties of the soils before and after the leaching. The results will help to further recognize the leaching remediation mechanisms of Cr-polluted soil.

\section{Materials and Methods}

\subsection{Soil}

The contaminated soil used for experiments was collected from the upper $20 \mathrm{~cm}$ surface layer at a Cr-containing slag heap site of Qingdao Hongxing Chemical Plant, China (longitude $120^{\circ} 23^{\prime} 18^{\prime \prime} \mathrm{E}$, latitude $36^{\circ} 12^{\prime} 21^{\prime \prime} \mathrm{N}$ ). Five samples ( $\mathrm{kg}$ per sample) were randomly collected from different locations, and then mixed thoroughly after returning to the laboratory. For soil analyses and column leaching experiment, the mixed samples were air-dried and sieved by a $2 \mathrm{~mm}$ sieve. The physical and chemical properties of the soil are shown in Table 1. 
Table 1. Physical and chemical properties of the soil.

\begin{tabular}{cc}
\hline Soil Property & Value \\
\hline Soil type & Alfisols (USDA soil taxonomy) \\
Soil texture & Sandy loam \\
Soil bulk density $\left(\mathrm{g} / \mathrm{cm}^{3}\right)$ & 1.36 \\
CEC $(\mathrm{cmol} / \mathrm{kg})$ & 2.62 \\
$\mathrm{pH}$ & 10.25 \\
Particle distribution $0.075-2 \mathrm{~mm}(\%)$ & 40.1 \\
OM $(\%)$ & 5.7 \\
Cr(VI) $(\mathrm{mg} / \mathrm{kg})$ & $328 \pm 21$ \\
Total Cr $(\mathrm{mg} / \mathrm{kg})$ & $3389 \pm 169$ \\
Total Ca $(\mathrm{mg} / \mathrm{kg})$ & $17,253 \pm 862$ \\
Total $\mathrm{Mg}(\mathrm{mg} / \mathrm{kg})$ & $7209 \pm 360$ \\
Total Fe $(\mathrm{mg} / \mathrm{kg})$ & $25,263 \pm 1268$ \\
Total $\mathrm{Mn}(\mathrm{mg} / \mathrm{kg})$ & $546 \pm 30$ \\
&
\end{tabular}

\subsection{Column Leaching Experiment}

The diagram of the leaching device is shown in Figure 1. The tube body of the soil column was made by plexiglass column with $50 \mathrm{~cm}$ length and an inner diameter of $2.5 \mathrm{~cm}$. Each column was filled with $200 \mathrm{~g}$ Cr-contaminated soil, with a depth of about $30 \mathrm{~cm}$. The bottom of the soil column was immersed in distilled water until the saturation equilibrium, based on the pre-determined saturated moisture content ( $40 \% \mathrm{wt}$. percentage). A $100 \mu \mathrm{m}$-aperture sand core was placed at the bottom of the column, and a 1-2 cm thick quartz layer was placed above the sand core and then loaded the soil into the column. Columns were leached continuously with $800 \mathrm{~mL} \mathrm{HCl}, \mathrm{CA}$, or OX, respectively. Based on our pre-experiments, the concentrations of the acids were set as $0.5 \mathrm{~mol} / \mathrm{L}$. The eluents depend on the pressure of the peristaltic pump to enter the soil column uniformly, and the flow rate was $0.75-1.00 \mathrm{~mL} / \mathrm{min}$, which was based on our pre-experiments. A volume of $40 \mathrm{~mL}$ acid was added at each time. The next $40 \mathrm{~mL}$ acid was added after $40 \mathrm{~mL}$ leachate of the former $40 \mathrm{~mL}$ acid was collected (about $12 \mathrm{~h}$ ) using a $50 \mathrm{~mL}$ beaker. The leachate was filtered into a $50 \mathrm{~mL}$ PE plastic bottle, and then $\mathrm{pH}$ value was determined immediately. The concentrations of $\mathrm{Ca}, \mathrm{Mg}, \mathrm{Fe}, \mathrm{Mn}$, and $\mathrm{Cr}$ in the leachate were determined using flame atomic absorption spectrometry (FAAS) (AA-7000, Shimadzu, Tokyo, Japan). After the leaching procedure, the soil in the column was air-dried and mixed thoroughly, and then sampled for further analysis.

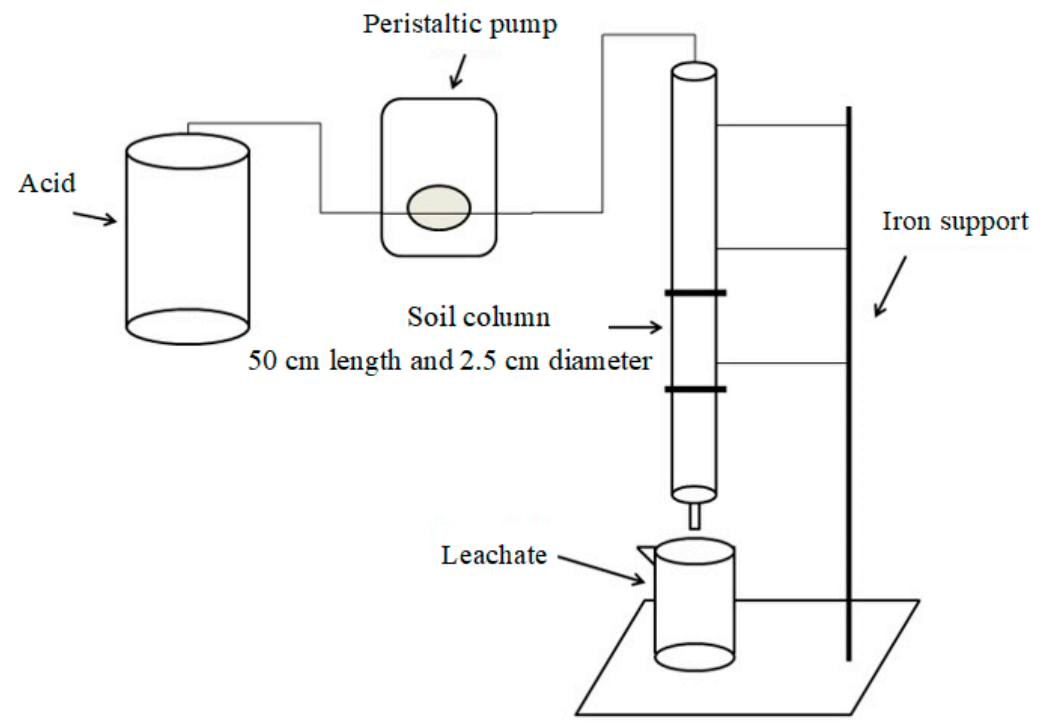

Figure 1. Diagram of the leaching device. 


\subsection{Mineralogical and Morphological Analysis}

Mineralogical characterization of soil samples was performed using an X-ray diffractometer (XRD) (Rigaku D/max-2500 PC, Rigaku Industrial Corp., Tokyo, Japan), operating with $\mathrm{Cu} \mathrm{K} \alpha$ radiation at $40 \mathrm{kV}$ and $150 \mathrm{~mA}$, scanning over the range $10-90^{\circ}$ in $2 \theta$, step size $0.02^{\circ}$. To analyze the overall size distribution and morphology of soil particles, and elemental composition, a scanning electron microscope (SEM) (S-4800, Hitachi, Tokyo, Japan) equipped with X-ray energy dispersive spectrometer (EDS) was used. The elemental analysis by EDS was performed in "point mode" in which the beam was positioned on a manually selected single area on SEM image $[15,16]$. Chemical states of $\mathrm{Cr}$ on the surface of soil samples before and after leaching were determined using an ESCALAB 250Xi X-ray photoelectron spectroscopy (XPS) (Thermo Fisher Scientific, Waltham, USA) with an Al K $\alpha$ X-ray source at a base pressure of $10^{-9}$ mbar. To compensate for surface charge effects, binding energies were calibrated using the $\mathrm{C} 1 \mathrm{~s}$ hydrocarbon peak at $284.8 \mathrm{eV}$. A narrow scanned spectra in the range of 567-596 eV was used to obtain the redox state information for the Cr. Peak fitting procedure and quantitative calculations of the surface atomic concentration of $\mathrm{Cr}$ were performed using XPS Peak software (version 4.1).

\subsection{Data Analysis}

The XRD data were analyzed using Jade 7.1.2 software (Jade Software Corp., Christchurch, New Zealand). The data were analyzed using SPSS 21.0 statistical software and Microsoft Office Excel 2010. One-way analysis of variance $(p<0.05)$, followed by the Tukey test, was performed to determine statistical significance between the different treatments. The Pearson correlation test was performed to determine the correlation between $\mathrm{Cr}$ concentrations and other metal concentrations in leachates.

\section{Result and Discussion}

\subsection{Leachate $\mathrm{pH}$ and Soil $\mathrm{pH}$}

The dynamic changes of the leachate $\mathrm{pH}$ were shown in Figure 2a. At the beginning of the leaching $(120 \mathrm{~mL})$, leachate was alkaline (>7.7). With the increase of the eluents volume, $\mathrm{pH}$ value showed a rapid decline. When the soil received $240 \mathrm{~mL} \mathrm{CA}, 320 \mathrm{~mL} \mathrm{OX}$, and $640 \mathrm{~mL} \mathrm{HCl}$, leachate $\mathrm{pH}$ decreased to $2.64,0.94$, and 0.68 , respectively, and then decreased slowly and stabilized at 1.6, 0.6 , and 0.5 thereafter. After the leaching procedure, $\mathrm{pH}$ values of soil treated with $\mathrm{HCl}, \mathrm{CA}$, and $\mathrm{OX}$ decreased significantly $(p<0.05)$ to $2.07,2.35$, and 3.20 , respectively (Figure $2 b$ ).
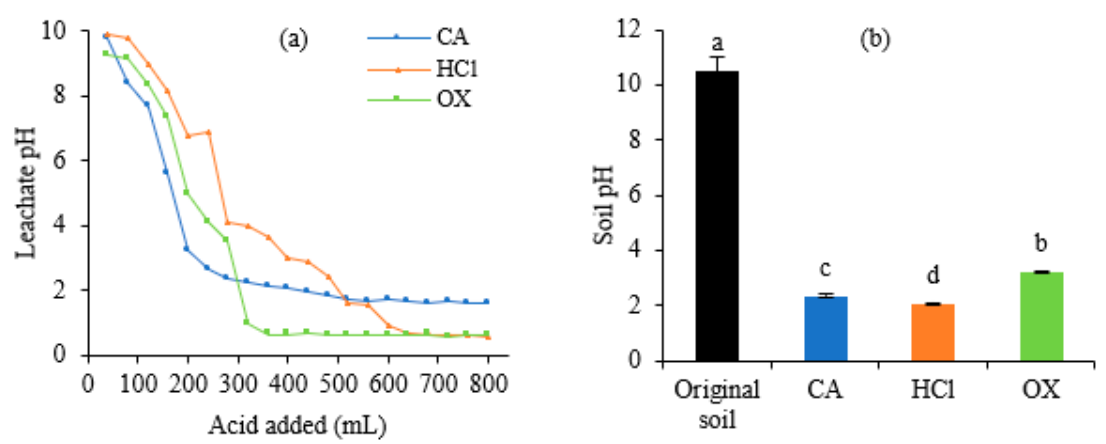

Figure 2. The $\mathrm{pH}$ values in the leachates and soils after leaching by different acids. (a) Leachates, (b) Soils. In Figure 2b, different letters on the bars indicate significant differences among the means in different treatments using a one-way analysis of variance followed by the Tukey test $(p<0.05)$.

Soil $\mathrm{pH}$ influences chemical processes and chemical reactions of metals in soil, such as oxidation, reduction, precipitation, adsorption, and coordination reaction [17]. It was found that there are two main modes on the leaching rates of metals being enhanced by acids from soils. The first is that 
acids would produce positively charged hydrogen atoms, inducing a multi-stage proton by $\mathrm{H}^{+}$or the replacement reaction of acid with metals [18]. The second is the dissolution reaction with the mineral crystal lattice of the soil by the $\mathrm{H}^{+}$absorbed to the surface of minerals $[6,19]$. The present results show that acid leaching could decrease soil $\mathrm{pH}$, which possibly increases the mobility of metals and then accelerates their leaching in the soil [20,21]. Among the three acids, OX caused the least soil acidification, which is of significance for re-use of the leached soil.

\subsection{Leaching Dynamics}

As shown in Figure 3a, the leaching loss of Ca mainly occurred in the first half stage of the leaching. At the end of the leaching, the cumulative removal of $\mathrm{Ca}$ by $\mathrm{HCl}, \mathrm{CA}$, and OX was 6176, 1347, and $86 \mathrm{mg} \mathrm{Ca} / \mathrm{kg}$ soil, respectively (Figure 4a). $\mathrm{HCl}$ leached much more $\mathrm{Ca}$ than $\mathrm{CA}$ and $\mathrm{OX}$, while OX showed the least leaching effect. For $\mathrm{CA}$, the peak value of leaching $\mathrm{Ca}$ was significantly earlier than the other two acids, indicating that $\mathrm{Ca}$ leaching by $\mathrm{CA}$ reaches the equilibrium state much sooner than leaching by the other two acids.

(a)

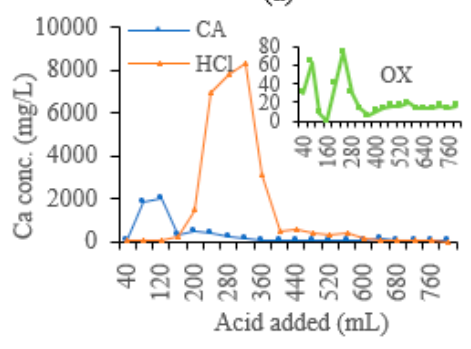

(c)

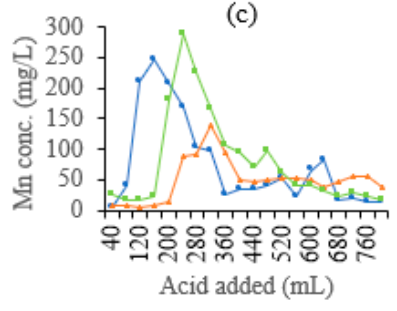

(b)

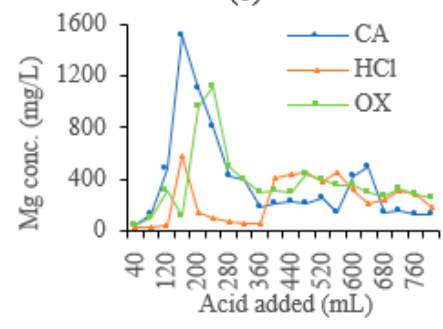

(d)

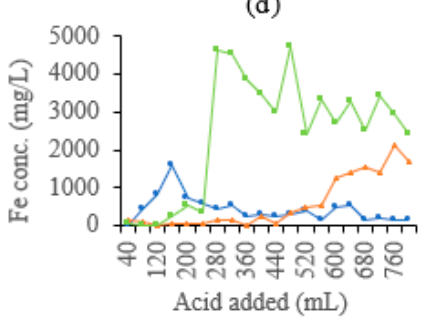

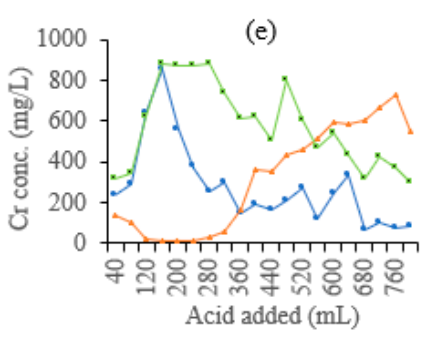

Figure 3. Dynamic concentrations of metals in leachates of the soils leached by different acids. (a) Ca, (b) $\mathrm{Mg}$, (c) $\mathrm{Mn}$, (d) Fe, (e) $\mathrm{Cr}$.
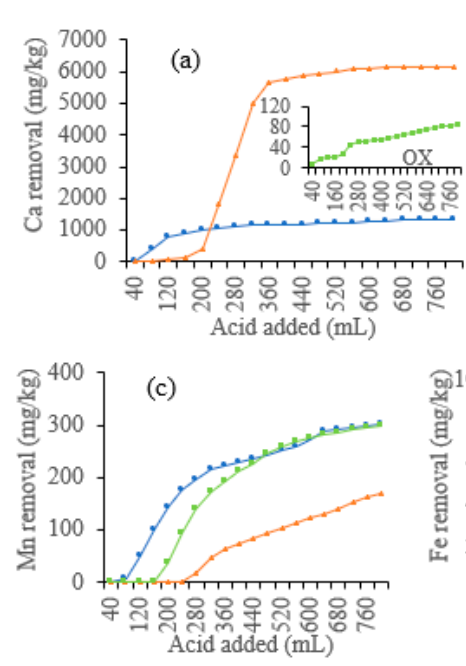
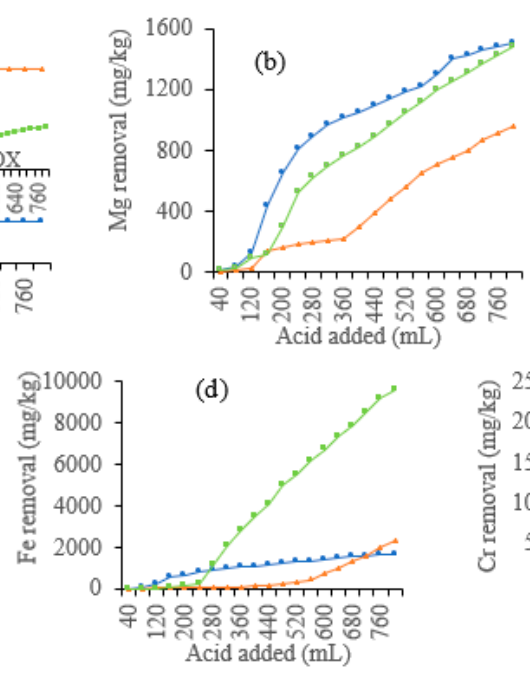

Figure 4. Cumulative removal of metals from the soils leached by different acids. (a) $\mathrm{Ca}$, (b) $\mathrm{Mg}$, (c) $\mathrm{Mn}$, (d) $\mathrm{Fe},(e) \mathrm{Cr}$. 
The dynamic leaching process of $\mathrm{Mg}$ and $\mathrm{Mn}$ was similar (Figure 3b,c). The leaching loss of $\mathrm{Mg}$ and Mn also occurred mainly in the first half leaching stage and decreased after reaching a summit value. The cumulative leaching amount of $\mathrm{Mg}$ and $\mathrm{Mn}$ gradually increased. CA and OX had similar cumulative leaching amounts of $\mathrm{Mg}(1512 \mathrm{mg} / \mathrm{kg}$ for CA, and $1483 \mathrm{mg} / \mathrm{kg}$ for OX) and Mn (301 mg/kg for CA, and $300 \mathrm{mg} / \mathrm{kg}$ for OX), which were much higher than the amounts leached by $\mathrm{HCl}(957 \mathrm{mg} / \mathrm{kg}$ $\mathrm{Mg}$ and $171 \mathrm{mg} / \mathrm{kg} \mathrm{Mn}$ ) (Figure $4 \mathrm{~b}, \mathrm{c}$ ). As organic acids, OX and CA showed similar effects on the leaching loss of $\mathrm{Mg}$ and $\mathrm{Mn}$, with a difference in the peak value of $\mathrm{CA}$ which appeared earlier than that of OX.

The dynamic leaching of $\mathrm{Fe}$ and $\mathrm{Cr}$ was shown in Figure 3d,e. OX had the most cumulative leaching amounts of $\mathrm{Fe}(9648 \mathrm{mg} / \mathrm{kg})$ and $\mathrm{Cr}(2304 \mathrm{mg} / \mathrm{kg})$ (Figure $4 \mathrm{~d}, \mathrm{e})$. Cr concentration first peaked at $160 \mathrm{~mL}$ leachate, with $838 \mathrm{mg} / \mathrm{L}$, while Fe concentration reached the first peak at $400 \mathrm{~mL}$ leachate, with $3448 \mathrm{mg} / \mathrm{L}$. Then, $\mathrm{Cr}$ and Fe reached the second peak concentrations at $480 \mathrm{~mL}$ leachate, with $801 \mathrm{mg} / \mathrm{L}$ and $4697 \mathrm{mg} / \mathrm{L}$, respectively. Fe and Cr dynamic concentrations reached peak values fastest in CA leachates, but CA showed the least cumulative leaching amounts $(1667 \mathrm{mg} / \mathrm{kg} \mathrm{Fe}$ and $1102 \mathrm{mg} / \mathrm{kg} \mathrm{Cr}$, respectively). Fe concentration in the leachate reached a peak and then decreased gradually. $\mathrm{HCl}$ also showed a poor ability to leach $\mathrm{Fe}(2345 \mathrm{mg} / \mathrm{kg})$ and $\mathrm{Cr}(1282 \mathrm{mg} / \mathrm{kg})$, with most of $\mathrm{Fe}$ and $\mathrm{Cr}$ being leached during the middle and late stages.

Acids are generally nonspecific agents which can leach diverse elements from soil. Soil washing with acids can lead to loss of the major component elements such as $\mathrm{Cu}, \mathrm{Zn}, \mathrm{Al}, \mathrm{Ca}, \mathrm{Mg}, \mathrm{Fe}$, and $\mathrm{Mn}$, and alter or even destroy soil structures $[10,22,23]$. CA would lead to leaching of major elements such as $\mathrm{Ca}, \mathrm{Mg}, \mathrm{Fe}, \mathrm{Al}, \mathrm{Mn}$ and $\mathrm{Zn}$, in addition to pollutants $\mathrm{Cr}$ and $\mathrm{Ni}[10,24]$. Our present results confirm that $\mathrm{HCl}, \mathrm{OX}$, and $\mathrm{CA}$ showed different capacities to leach $\mathrm{Cr}$ out of the soil, as well as essential nutrients for plants, $\mathrm{Ca}, \mathrm{Mg}, \mathrm{Fe}$, and $\mathrm{Mn}$, indicating the dissolution of soil mineral nutrients by both inorganic and organic acids. Acids that can effectively leach toxic metals but not nutrients should be selected for their potential applications in soil washing.

Our results show that acids vary greatly in their ability to leach different metals, with different dynamics and cumulative amounts of different metals. From the point of view of the total metals leached, OX generally had the most remarkable ability to leach $\mathrm{Cr}, \mathrm{Fe}, \mathrm{Mg}$, and $\mathrm{Mn}$, but the poorest ability to leach $\mathrm{Ca}$. OX can effectively leach $\mathrm{Cr}$ via forming water-soluble chromium oxalate [25]. Reductive and ligand-promoted dissolution mechanisms may explain the effective extraction of $\mathrm{Cr}$, $\mathrm{Fe}$, and Mn by OX [26], but calcium oxalate precipitation formed between OX and Ca may allow the retention of $\mathrm{Ca}$ in soil. $\mathrm{HCl}$ leached the largest amount of $\mathrm{Ca}$. Among the acids used in the present study, $\mathrm{HCl}$ has the strongest acidity, and can dissolve crystal lattices of the minerals in soils, and thus calcium carbonate would be dissolved to soluble $\mathrm{Ca}^{2+}$ by $\mathrm{HCl}$ [6]. Overall, $\mathrm{CA}$ leached similar amounts of $\mathrm{Mg}$ and $\mathrm{Mn}$ to $\mathrm{OX}$, and similar amounts of $\mathrm{Fe}$ and $\mathrm{Cr}$ to $\mathrm{HCl}$.

However, the metal concentrations in the leachates depend on not only acids but also metal species. Generally, Fe, Ca, and $\mathrm{Cr}$ are easier to be leached than $\mathrm{Mg}$ and $\mathrm{Mn}$ (Figure 4). This is in accordance with the previous findings of Jean-Soro et al. [10]. The leaching of Mn may be explained by the less content $(546 \mathrm{mg} / \mathrm{kg}$ ) in soil, while such explanations cannot explain the leaching of $\mathrm{Mg}$, which is about $7209 \mathrm{mg} / \mathrm{kg}$ in soil, much higher than that of $\mathrm{Cr}$. There must be other mechanisms deserving further investigation.

As for the leaching dynamics, the concentrations of $\mathrm{Ca}, \mathrm{Mg}$, Mn, Fe, and $\mathrm{Cr}$ (except for the $\mathrm{HCl}$ leaching of $\mathrm{Fe}$ and $\mathrm{Cr}$ ) in the leachates generally increased to a peak, and then decreased slowly in the first $400 \mathrm{~mL}$ leachates, which had no significant correlation with leachate $\mathrm{pH}$. There are two or more peaks during the leaching of $\mathrm{Mg}$ and $\mathrm{Mn}$, with the larger peak in the first half stage and the smaller peak in the second half stage. However, in the process of $\mathrm{Fe}$ and $\mathrm{Cr}$ leaching by $\mathrm{HCl}$, the concentrations of these two metals in the leachate varied irregularly all the time and even higher in the final stage, indicating a significant lag effect.

Metals in soil are generally bound to different soil fractions with different bonding forces, which may determine their extractability. For example, some metal ions that associate with functional groups 
of soil organic matters via complexation reaction are difficult to be desorbed, while those electrostatically adsorbed on the charge of soil colloids are much easier to be desorbed $[17,27,28]$. Coordinate-covalent bonding mainly occurs in inner-sphere metal complexes, whereas electrostatic bonding dominates outer-sphere complexes, which determines that inner-sphere complexes are generally more stable than outer-sphere complexes [29]. Understandably, the rapidly desorbed ions will have a fast increase in concentration in leachates, while those specifically adsorbed metals are generally desorbed slowly, resulting in an increase in concentration followed by a slow release in the initial leaching process [17]. These findings can also explain our present results that the metals have different leaching dynamics.

\subsection{Correlation Analysis}

As shown in Figure S1 (see Supplementary file for additional information), in most cases, linear relationships occurred between $\mathrm{Cr}$ and other metals. Cr always correlated positively with $\mathrm{Mg}$ and correlated positively with $\mathrm{Fe}$ in $\mathrm{CA}$ and $\mathrm{HCl}$ leachates, and $\mathrm{Mn}$ in $\mathrm{CA}$ and $\mathrm{OX}$ leachates. It has been shown that $\mathrm{Cr}$ and $\mathrm{Mn}$ had a highly positive correlation, as iron-manganese-rich oxides on the surface of mafic minerals coexist with $\mathrm{Cr}$ [30]. Our earlier study also found that the proportion of oxidized $\mathrm{Cr}$ (Fe-Mn-bound forms) in the soil was higher than other speciation. After leaching, the proportion of the oxidized $\mathrm{Cr}$ decreased significantly (unpublished data).

In addition, $\mathrm{Cr}$ correlated positively with $\mathrm{Ca}$ in $\mathrm{CA}$ leachates, but negatively with $\mathrm{Ca}$ in $\mathrm{HCl}$ leachates, and not significantly with $\mathrm{Ca}$ in OX leachates. $\mathrm{Cr}$ and $\mathrm{Ca}$ in minerals had different chemical behaviors when different acids were used in leaching. Ca forms stable complexes with oxalate and citrate [31,32], but dissolves readily in strong acid such as $\mathrm{HCl}$, which may partly explain the contradictory correlations between $\mathrm{Cr}$ and $\mathrm{Ca}$ in different leachates.

\subsection{XRD Analysis}

The mineralogical components of the soils before and after leaching were analyzed by XRD (Figure 5). The original soil was characterized by the main mineral quartz, as well as other minor minerals, such as orthoclase, tamarugite, albite, microcline, zeolite and other silicate minerals (Figure 4a). Previous results have found several soil crystalline phases, particularly calcite, vermiculite and illite, can rapidly and fully dissolve under low soil pH conditions [33,34]. In our present study, on one hand, some diffraction peaks disappeared after leaching, suggesting the removal of some phases by the acids. On the other hand, some new crystalline phases generated as a result of the dissolution of acids, which was indicated by the appearance of the XRD peaks, especially albite and silicate-based minerals. Acid dissolution and metal ions complexing reactions of the organic acids may account for stimulating soil metal release and generation of new mineral (chromium chloride). Noteworthily, after leaching, the diffraction peaks of zeolite were observed only in OX-leached soil, suggesting this mineral was difficult to be decomposed by OX, and this can also explain the poor removal for Ca by OX.

XRD technique in combination with other synchrotron $\mathrm{X}$-ray microanalytical analysis was used to confirm the geochemical forms (chromite and zincochromite) of $\mathrm{Cr}$ in a soil from an industrial polluted site [35]. In soils derived from fluvioglacial sands, $\mathrm{Cr}$ was predominantly in the fraction bound with iron and manganese oxides [36]. In the present study, XRD analysis showed that, the crystalline phases of the $\mathrm{Cr}$-contained minerals detected in the original soil included magnesium chromate $(\mathrm{VI})\left(\mathrm{MgCrO}_{4}\right)$, potassium calcium chromium (III) fluor $\left(\mathrm{KCaCr}_{2} \mathrm{~F}_{9}\right)$, and chromium (III) vanadium oxide $\left(\mathrm{CrVO}_{4}\right)$, exhibiting strong peaks between 26-28 . Compared with the original soil, the peaks of $\mathrm{MgCrO}_{4}$ and $\mathrm{KCaCr}_{2} \mathrm{~F}_{9}$ disappeared in all the leached soils. This is due to the facts that $\mathrm{MgCrO}_{4}$ and $\mathrm{KCaCr}_{2} \mathrm{~F}_{9}$ are more easily decomposed and dissolved by acids. However, the insoluble $\mathrm{CrVO}_{4}$ was detected in the original and leached soils. In addition, in the soil after $\mathrm{HCl}$ leaching, chromium chloride $\left(\mathrm{CrCl}_{3}\right)$ was also detected, which probably originated from the combination of residual $\mathrm{Cl}^{-}$and $\mathrm{Cr}(\mathrm{III})$. No other Cr-minerals were observed in the XRD results. 
(a)

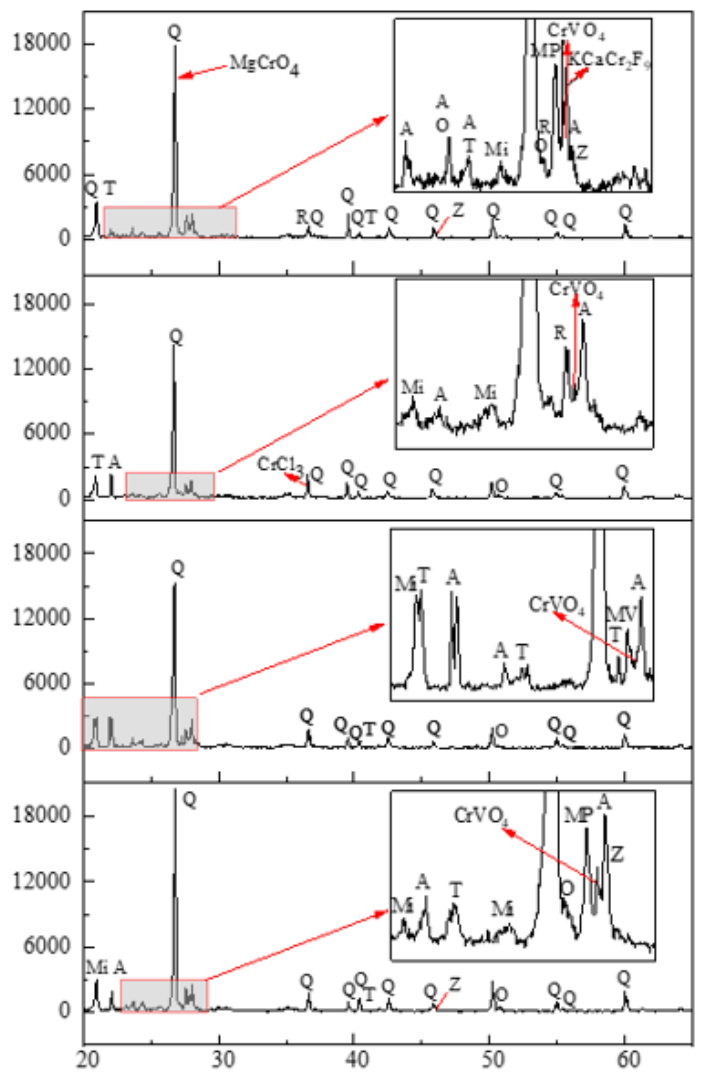

Q: Quartz, syn- $\mathrm{SiO}_{2}$

T: Tamarugite- $\mathrm{NaAl}\left(\mathrm{SO}_{4}\right)_{2} \cdot 6 \mathrm{H}_{2} \mathrm{O}$

$\mathrm{R}$ : Rhodium Vanadium Oxide- $\mathrm{RhVO}_{4}$

$\mathrm{O}:$ Orthoclase- $\mathrm{KAlSi}_{3} \mathrm{O}_{3}$

MP: $\mathrm{Mn}_{3}\left(\mathrm{PO}_{4}\right)_{3}-$ Manganese Phosphate

MV: Manganese Vanadium Oxide-

$\mathrm{Mn}_{2} \mathrm{~V}_{2} \mathrm{O}_{7}$

$\mathrm{CrVO}_{4}$ : Chromium Vanadium Oxide

$\mathrm{CrCl}_{3}$ : Chromium Chloride

$\mathrm{KCaCr}_{2} \mathrm{~F}_{9}$ : Potassium Calcium

Chromium Fluor

A: Albite, calcian, ordered-

$(\mathrm{Na}, \mathrm{Ca}) \mathrm{Al}(\mathrm{Si}, \mathrm{Al})_{3} \mathrm{O}_{3}$

$\mathrm{MgCrO}_{4}$ : Magnesium chromate(VI)

Z: Zeolite

Mi: microcline, $\mathrm{KAlSi}_{3} \mathrm{O}_{8}$

Figure 5. X-ray diffraction patterns of the soils before and after leaching by different acids. (a) Original soil, (b) soil leached by $\mathrm{HCl}$, (c) soil leached by CA, (d) soil leached by OX.

\subsection{SEM-EDS Analysis}

The morphology of the test soils was determined using SEM-EDS (Figure 6). The original soil and HCl-treated soil had smooth surfaces with fine grains on them (Figure 6a,b). Cerqueira et al. [37] observed $\mathrm{Cu}$ and $\mathrm{Cd}$ spotted on the surface of soil particles, and the coexistence of amorphous iron oxides, vermiculite, gibbsite, and organic matter aggregates containing $\mathrm{Cu}$, and vermiculite and gibbsite aggregates containing $\mathrm{Cd}$. Using field emission scanning electron microscopy (FE-SEM) with energy-dispersive $\mathrm{X}$-ray spectroscopy (EDS) techniques, $\mathrm{Cu}$ was found on the surface of amorphous iron oxides and associated with schwertmannite [38]. Fe-rich spherules and irregular particles were commonly observed particles in technogenic magnetic particles in industrially contaminated soils, revealing various Fe contents often associated with elevated heavy metal contents [15]. After leaching by organic acids, soils showed significant morphological changes: the surfaces of soil particles became rougher and no fine-grained structures were observed (Figure $6 c, d$ ). Considering the chelation of metals by organic acids, it could be inferred that the leaching of $\mathrm{Cr}$ and other metal elements in the soil was related to the disappearance of these fine grains. Smaller grains have a higher specific surface area and more reaction sites, so they could be dissolved faster by acids. These results are in accordance with previous findings that heavy metals in soils were combined with certain components and showed a punctate distribution in soil particles $[39,40]$.

Elemental analysis of soils before and after leaching was determined by EDS (Figure 6). The peaks of $\mathrm{O}, \mathrm{Si}$, and $\mathrm{Al}$ in the original soil samples were higher than those of $\mathrm{Ca}, \mathrm{Fe}, \mathrm{Na}, \mathrm{Mg}, \mathrm{K}$, and $\mathrm{Cr}$. This indicates that chemical constituent elements of the original soil microstructure are mainly $\mathrm{O}, \mathrm{Si}$, $\mathrm{Al}, \mathrm{Ca}, \mathrm{Fe}, \mathrm{Mg}, \mathrm{K}, \mathrm{Cr}$, and other trace elements, at least on the surface or near-surface layer. Combined with the results of XRD analysis (Figure 5), it can be inferred that the minerals of the original soil are mainly composed of silicon dioxide or silicate, and the clay minerals were mainly crystalline or non-crystalline silicates composed of $\mathrm{Si}$ tetrahedron or $\mathrm{Al}$ octahedron and free-state aluminosilicates. 

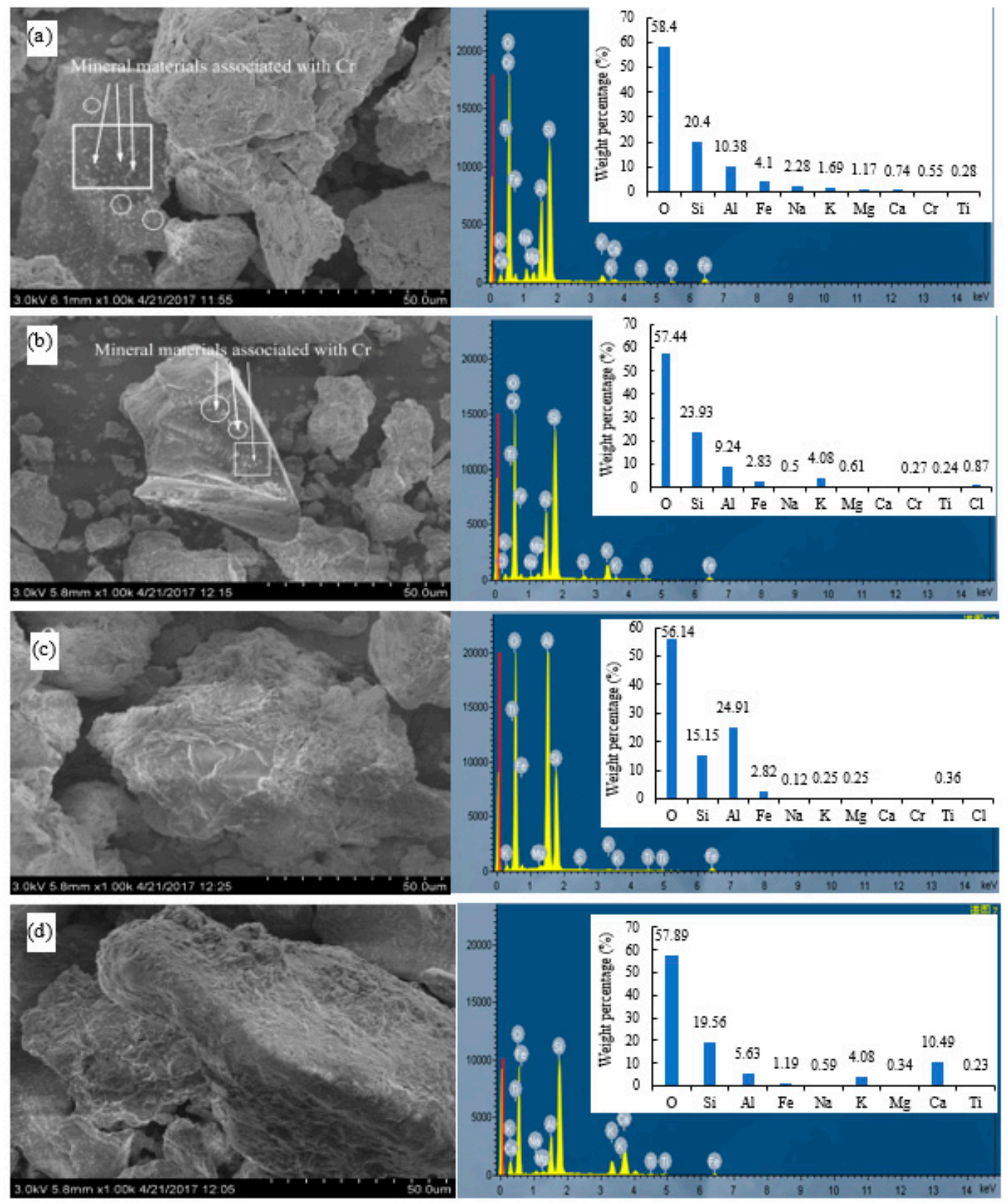

Figure 6. SEM image and EDS of the soils before and after leaching by different acids. (a) Original soil, (b) soil leached by $\mathrm{HCl}$, (c) soil leached by CA, (d) soil leached by OX.

Since organic acids can chelate metals in the process of leaching $[7,10,26]$, the metals in the soil matrix minerals may form chelates with organic acids that could be separated from the soil particle surface. As shown in Figure 6, the distribution and content of elements in the soil after leaching showed a great change. Cr was not detected in the soil surfaces after leaching by CA and OX but was detectable in the original soil and the soil leached by $\mathrm{HCl}$, with a weight percentage of $\mathrm{Cr}$ at $0.55 \%$ and $0.27 \%$, respectively. Our results suggest that organic acids could effectively desorb $\mathrm{Cr}$ in soil particle surface. A remediation strategy using the two organic acids is recommended for $\mathrm{Cr}$-contaminated soil.

The results of EDS analysis are in agreement with the cumulative leaching loss of the metals $(\mathrm{Ca}$, $\mathrm{Mg}$, and $\mathrm{Fe}$ ) monitored in the leachates (Figure 4). The percentages of $\mathrm{O}, \mathrm{Si}$, and $\mathrm{Al}$ in all the soils leached by acids were still higher than other elements. In the HCl-leached soil, the weight percentages of $\mathrm{Na}, \mathrm{Mg}, \mathrm{Ca}$, and Fe decreased, and those of $\mathrm{Si}$ and $\mathrm{K}$ increased. At the same time, the content of $\mathrm{Cl}$ 
increased after leaching by $\mathrm{HCl}$, which was evidently introduced by the $\mathrm{HCl}$ added. In the CA-leached soil, the weight percentages of $\mathrm{Fe}, \mathrm{Na}, \mathrm{K}, \mathrm{Mg}$, and Ca decreased, while the weight percentage of $\mathrm{Al}$ increased significantly, which may be due to the formation of insoluble aluminum-citrate complexes. After leaching by $\mathrm{OX}$, the weight percentages of $\mathrm{Al}, \mathrm{Fe}, \mathrm{Na}$, and $\mathrm{Mg}$ significantly decreased, while those of $\mathrm{Ca}$ and $\mathrm{K}$ were much higher than in original soil, indicating that $\mathrm{OX}$ has good retention effects on $\mathrm{Ca}$ and $\mathrm{K}$. The elements $\mathrm{Ca}$ and $\mathrm{K}$ are not only essential for plant nutrition but are also important for maintenance of healthy soil structure [41,42]. Therefore, OX may be more environment-friendly than $\mathrm{CA}$ and $\mathrm{HCl}$ for soil washing, which is of great importance for subsequent applications of the remediated soil in plant growth and production [43].

\subsection{XPS Analysis}

XPS analysis provides the information on oxidation states of the $\mathrm{Cr}$ elements before and after leaching (Figure 7). The results showed that various chemical states of $\mathrm{Cr}$ occurred in the original soil, including $\mathrm{Cr}(\mathrm{III}), \mathrm{Cr}(\mathrm{VI})$, and some other unknown states. Based on the height and area of the peaks, $\mathrm{Cr}$ (III) represented the highest proportion. After acid leaching, the heights and areas of all the peaks decreased, suggesting that these acids were effective for removal of all the states of Cr. This is also confirmed by the $\mathrm{Cr}$ atomic concentrations based on XPS analysis, with a decreasing order of the original soil $(1.25 \%)>\mathrm{HCl}$ leached soil $(1.03 \%)>$ CA leached soil $(0.83 \%)>$ OX leached soil $(0.57 \%)$. However, compared to $\mathrm{HCl}, \mathrm{OX}$, and $\mathrm{CA}$, this showed a significantly higher removal for total, trivalent $\mathrm{Cr}$, and hexavalent $\mathrm{Cr}$. These results suggest that chelation through ligand complexing of $\mathrm{Cr}(\mathrm{III})$, in addition to acid dissolution, may be the main mechanisms responsible for $\mathrm{Cr}$ (III) removal by organic acids. The main $\mathrm{Cr}(\mathrm{VI})$ compound based on the $\mathrm{XRD}$ analysis was water-soluble $\mathrm{MgCrO}_{4}$, which may explain the effective removal of $\mathrm{Cr}(\mathrm{VI})$ by all three acids. $\mathrm{HCl}$ has a stronger acidity, but showed no higher removal for $\mathrm{Cr}(\mathrm{VI})$ than $\mathrm{OX}$ and $\mathrm{CA}$, indicating other different mechanisms such as competitive desorption, or reduction of $\mathrm{Cr}(\mathrm{VI})$ to $\mathrm{Cr}(\mathrm{III})$ and the subsequent chelation of $\mathrm{Cr}(\mathrm{III})$ may occur in $\mathrm{Cr}(\mathrm{VI})$ removal by $\mathrm{OX}$ and $\mathrm{CA}$.

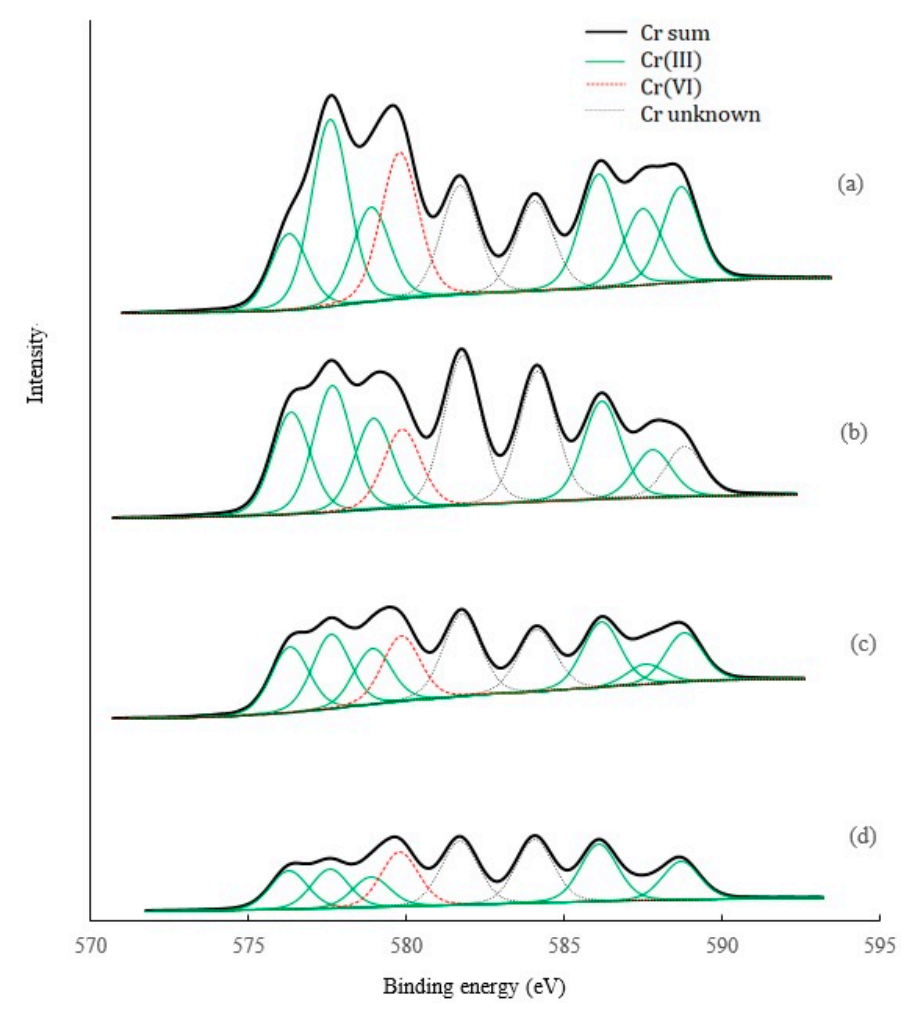

Figure 7. XPS analysis of $\mathrm{Cr}$ species in the soils before and after leaching by different acids. (a) Original soil, (b) soil leached by $\mathrm{HCl}$, (c) soil leached by CA, (d) soil leached by OX. 
Previous studies have shown OX to have a significant role in both $\mathrm{Cr}(\mathrm{VI})$ reduction and $\mathrm{Cr}(\mathrm{III})$ complexation $[14,44,45]$. CA also can increase the reduction of $\mathrm{Cr}(\mathrm{VI})$ and the subsequent formation of soluble $\mathrm{Cr}$ (III)-citrate [45], and solubilize the $\mathrm{Cr}$ (III) by complexation and desorb the $\mathrm{Cr}(\mathrm{VI})$ by competition for surface sites [24]. These mechanisms are probably involved in the removal of $\mathrm{Cr}$, as well as $\mathrm{Fe}, \mathrm{Mn}, \mathrm{Ca}$, and $\mathrm{Mg}$, in our present study. Evidently, these mechanisms are not involved in $\mathrm{Cr}$-leaching by $\mathrm{HCl}$. Furthermore, compared to $\mathrm{CA}, \mathrm{OX}$ is a strong acid, and $\mathrm{OX}$ of the same quality can provide more ligands $(-\mathrm{COOH})$. These facts can explain why OX possesses a higher removal ability than CA.

Unsurprisingly, acid leaching has several disadvantages, such as disturbing soil structure, causing losses of soil nutrients and increased acidity, and generating a large amount of leachate wastewater. Compared to the remediation techniques based on immobilization technology that cannot remove metals from the contaminated sites, acid leaching is one of the few remediation techniques that is efficient in extracting metals from the soils. For those highly contaminated sites where toxic metals are required to be separated from the soil, acid washing may be an ideal alternative. Particularly, compared to $\mathrm{HCl}, \mathrm{OX}$ as a biodegradable organic acid leached more $\mathrm{Cr}$ but caused less acidity, suggesting a potential in the leaching remediation of Cr-polluted soil.

\section{Conclusions}

Acid leaching could decrease soil $\mathrm{pH}$, causing soil acidification. OX leached much more $\mathrm{Cr}$ than $\mathrm{CA}$ and $\mathrm{HCl}$, indicating that $\mathrm{OX}$ can be used in leaching remediation of $\mathrm{Cr}$-contaminated soil. $\mathrm{Ca}, \mathrm{Mg}, \mathrm{Mn}$, and Fe were also leached by the three acids, and in most cases, correlated positively with Cr. Results from XRD, SEM-EDS combined with XPS techniques confirmed that Cr mainly interacted with soil minerals and showed a punctate distribution on soil particle surfaces. Soil mineralogical and morphological properties were significantly changed after leaching by acids. In the process of acid leaching, clay minerals, primary silicate minerals, and carbonate minerals in the soil would be decomposed, so that $\mathrm{Cr}$ and other metal elements ( $\mathrm{Ca}, \mathrm{Mg}, \mathrm{Mn}$, and $\mathrm{Fe}$ ) were released into leachate. In addition to the acid dissolution, the ligand complexation of $\mathrm{Cr}(\mathrm{III})$, competitive desorption, and reduction of $\mathrm{Cr}(\mathrm{VI})$ may represent the main mechanisms underlying $\mathrm{Cr}$ leaching by $\mathrm{OX}$ and $\mathrm{CA}$. The concomitant removal of other non-targeted metals occurred during the leaching remediation of Cr-contaminated soil, leading to loss of soil mineral nutrients and fertility. Overall, OX leached more $\mathrm{Cr}$ but less $\mathrm{Ca}$, and produced smaller soil acidification, and thus can function as an effective and environment-friendly extractant in the leaching remediation of Cr-contaminated soil.

Supplementary Materials: The following are available online at http://www.mdpi.com/1660-4601/16/15/2771/s1, Figure S1. Correlation between $\mathrm{Cr}$ and other metal concentrations in the leachates of $\mathrm{HCl}(\mathrm{a}), \mathrm{CA}(\mathrm{b})$ and $\mathrm{OX}$ (c). (ns not significant; * correlation is significant at $p<0.05$; ${ }^{* *}$ correlation is significant at $p<0.01$ ).

Author Contributions: F.G. and F.W. wrote the manuscript. Y.S. and F.W. designed the study. W.Y. and F.W. carried out the analyses. All authors approved the final version of the manuscript.

Funding: This work was supported by the National Natural Science Foundation of Shandong Province (ZR2018MD006), the National Natural Science Foundation of China (41471395), the Key Research and Development Program of Shandong Province (2019GSF109008), and the Doctoral Foundation of QUST (0100229003), and Education Department of Guizhou Province Key Laboratory of Soil Resources and Environment in Qianbei of Guizhou Province (Qian Jiao He KY Zi[2017]010).

Acknowledgments: We thank Chen Tu, from Yantai Institute of Coastal Zone Research, Chinese Academy of Sciences, for his help on conducting analysis.

Conflicts of Interest: The authors declare no conflict of interest.

\section{References}

1. Palmer, C.D.; Wittbrodt, P.R. Processes affecting the remediation of chromium-contaminated sites. Environ. Health Perspect. 1991, 92, 25-40. [CrossRef] [PubMed] 
2. Cohen, M.D.; Kargacin, B.; Klein, C.B.; Costa, M. Mechanisms of chromium carcinogenicity and toxicity. Crit. Rev. Toxicol. 1993, 23, 255-281. [CrossRef] [PubMed]

3. Dhal, B.; Thatoi, H.N.; Das, N.N.; Pandey, B.D. Chemical and microbial remediation of hexavalent chromium from contaminated soil and mining/metallurgical solid waste: A review. J. Hazard. Mater. 2013, 250, $272-291$. [CrossRef]

4. Chen, Y.; Dong, B.; Jia, X. Occurrence and fractionation of $\mathrm{Cr}$ along the Loushan River affected by a chromium slag heap in East China. Environ. Sci. Pollut. Res. Int. 2017, 24, 15655-15666. [CrossRef]

5. Yao, Z.; Li, J.; Xie, H.; Yu, C. Review on remediation technologies of soil contaminated by heavy metals. Procedia Environ. Sci. 2012, 16, 722-729. [CrossRef]

6. Udovic, M.; Lestan, D. EDTA and $\mathrm{HCl}$ leaching of calcareous and acidic soils polluted with potentially toxic metals: Remediation efficiency and soil impact. Chemosphere 2012, 88, 718-724. [CrossRef] [PubMed]

7. Onireti, O.O.; Lin, C.; Qin, J. Combined effects of low-molecular-weight organic acids on mobilization of arsenic and lead from multi-contaminated soils. Chemosphere 2017, 170, 161-168. [CrossRef]

8. Dermont, G.; Bergeron, M.; Mercier, G.; Richer-Laflèche, M. Soil washing for metal removal: A review of physical/chemical technologies and field applications. J. Hazard. Mater. 2008, 152, 1-31. [CrossRef] [PubMed]

9. Liu, L.; Li, W.; Song, W.; Guo, M. Remediation techniques for heavy metal-contaminated soils: Principles and applicability. Sci. Total Environ. 2018, 633, 206-219. [CrossRef] [PubMed]

10. Jean-Soro, L.; Bordas, F.; Bollinger, J.C. Column leaching of chromium and nickel from a contaminated soil using EDTA and citric acid. Environ. Pollut. 2012, 164, 175-181. [CrossRef]

11. Wasay, S.; Barrington, S.; Tokunaga, S. Remediation of soils polluted by heavy metals using salts of organic acids and chelating agents. Environ. Technol. 1998, 19, 369-379. [CrossRef]

12. Römkens, P.; Bouwman, L.; Japenga, J.; Draaisma, C. Potentials and drawbacks of chelate-enhanced phytoremediation of soils. Environ. Pollut. 2002, 116, 109-121. [CrossRef]

13. Ash, C.; Drábek, O.; Tejnecký, V.; Jehlička, J.; Michon, N.; Borůvka, L. Sustainable soil washing: Shredded card filtration of potentially toxic elements after leaching from soil using organic acid solutions. PLoS ONE 2016, 11, e0149882. [CrossRef] [PubMed]

14. Jiang, B.; Gong, Y.; Gao, J.; Sun, T.; Liu, Y.; Oturan, N.; Oturan, M.A. Reductive detoxification of Cr (VI) mediated by environmentally relevant carboxylic acids: State-of-the-art and perspectives. J. Hazard. Mater. 2019, 365, 205-226. [CrossRef] [PubMed]

15. Bourliva, A.; Papadopoulou, L.; Aidona, E.; Giouri, K.; Simeonidis, K.; Vourlias, G. Characterization and geochemistry of technogenic magnetic particles (TMPs) in contaminated industrial soils: Assessing health risk via ingestion. Geoderma 2017, 295, 86-97. [CrossRef]

16. Zhao, Y.; Zeng, F.; Liang, H.; Tang, Y.; Li, M.; Xiang, J.; Wen, X. Chromium and vanadium bearing nanominerals and ultra-fine particles in a super-high-organic-sulfur coal from Ganhe coalmine, Yanshan Coalfield, Yunnan, China. Fuel 2017, 203, 832-842. [CrossRef]

17. Qiao, J.; Sun, H.; Luo, X.; Zhang, W.; Mathews, S.; Yin, X. EDTA-assisted leaching of Pb and Cd from contaminated soil. Chemosphere 2017, 167, 422-428. [CrossRef]

18. Arwidsson, Z.; ElghDalgren, K.; Kronhelm, T.V.; Sjöberg, R.; Allard, B.; Hees, P.V. Remediation of heavy metal contaminated soil washing residues with amino polycarboxylic acids. J. Hazard. Mater. 2010, $173,697$. [CrossRef] [PubMed]

19. Tampouris, S.; Papassiopi, N.; Paspaliaris, I. Removal of contaminant metals from fine grained soils, using agglomeration, chloride solutions and pile leaching techniques. J. Hazard. Mater. 2001, 84, $297-319$. [CrossRef]

20. Li, L.; Wu, H.; van Gestel, C.A.; Peijnenburg, W.J.; Allen, H.E. Soil acidification increases metal extractability and bioavailability in old orchard soils of Northeast Jiaodong Peninsula in China. Environ. Pollut. 2014, 188, 144-152. [CrossRef] [PubMed]

21. Bolan, N.; Kunhikrishnan, A.; Thangarajan, R.; Kumpiene, J.; Park, J.; Makino, T.; Kirkham, M.B.; Scheckel, K. Remediation of heavy metal(loid)s contaminated soils-To mobilize or to immobilize? J. Hazard. Mater. 2014, 266, 141-166. [CrossRef] [PubMed]

22. Tsang, D.C.; Zhang, W.; Lo, I.M. Copper extraction effectiveness and soil dissolution issues of EDTA-flushing of artificially contaminated soils. Chemosphere 2007, 68, 234-243. [CrossRef] [PubMed] 
23. Kim, C.; Lee, Y.; Ong, S.K. Factors affecting EDTA extraction of lead from lead-contaminated soils. Chemosphere 2003, 51, 845-853. [CrossRef]

24. Jean, L.; Bordas, F.; Bollinger, J.C. Chromium and nickel mobilization from a contaminated soil using chelants. Environ. Pollut. 2007, 147, 729. [CrossRef] [PubMed]

25. Humar, M.; Pohleven, F.; Šentjurc, M. Effect of oxalic, acetic acid, and ammonia on leaching of $\mathrm{Cr}$ and $\mathrm{Cu}$ from preserved wood. Wood Sci. Technol. 2004, 37, 463-473. [CrossRef]

26. Lee, J.C.; Kim, E.J.; Kim, H.W.; Baek, K. Oxalate-based remediation of arsenic bound to amorphous Fe and $\mathrm{Al}$ hydrous oxides in soil. Geoderma 2016, 270, 76-82. [CrossRef]

27. Selim, H.M.; Buchter, B.; Hinz, C.; Ma, L. Modeling the transport and retention of cadmium in soils: Multireaction and multicomponent approaches. Soil Sci. Soc. Am. J. 1992, 56, 1004-1015. [CrossRef]

28. Naidu, R.; Bolan, N.S.; Kookana, R.S.; Tiller, K.G. Ionic-strength and pH effects on the sorption of cadmium and the surface charge of soils. Eur. J. Soil Sci. 2010, 45, 419-429. [CrossRef]

29. Bradl, H.B. Adsorption of heavy metal ions on soils and soils constituents. J. Colloid Interface Sci. 2004, 277, 1-18. [CrossRef] [PubMed]

30. Kazakis, N.; Kantiranis, N.; Voudouris, K.S.; Mitrakas, M.; Kaprara, E.; Pavlou, A. Geogenic Cr oxidation on the surface of mafic minerals and the hydrogeological conditions influencing hexavalent chromium concentrations in groundwater. Sci. Total Environ. 2015, 514, 224-238. [CrossRef]

31. Veeken, A.H.M.; Hamelers, H.V.M. Removal of heavy metals from sewage sludge by extraction with organic acids. Water Sci. Technol. 1999, 40, 129-136. [CrossRef]

32. Dinkelaker, B.; Römheld, V.; Marschner, H. Citric acid excretion and precipitation of calcium citrate in the rhizosphere of white lupin (Lupinus albus L). Plant. Cell Environ. 1989, 12, 285-292. [CrossRef]

33. González-Núñez, R.; Alba, M.D.; Orta, M.M.; Vidal, M.; Rigol, A. Remediation of metal-contaminated soils with the addition of materials-part II: Leaching tests to evaluate the efficiency of materials in the remediation of contaminated soils. Chemosphere 2012, 87, 829-837. [CrossRef] [PubMed]

34. Galán, E.; Carretero, M.I.; Fernándezcaliani, J.C. Effects of acid mine drainage on clay minerals suspended in the Tinto River (Rio Tinto, Spain). An experimental approach. Clay Miner. 1999, 34, 99-108. [CrossRef]

35. Roberto, T.; Matteo, S.; Bart, V.; Wout, D.N.; Koen, J.; Gerald, F.; Saverio, F.; Pacifico, R. Assessing the origin and fate of $\mathrm{Cr}, \mathrm{Ni}, \mathrm{Cu}, \mathrm{Zn}, \mathrm{Pb}$, and $\mathrm{V}$ in industrial polluted soil by combined microspectroscopic techniques and bulk extraction methods. Environ. Sci. Technol. 2007, 41, 6762-6769.

36. Jeske, A.; Gworek, B. Chromium, nickel and vanadium mobility in soils derived from fluvioglacial sands. J. Hazard. Mater. 2012, 237, 315-322.

37. Cerqueira, B.; Arenas-Lago, D.; Andrade, M.L.; Vega, F.A. Using time of flight secondary ion mass spectrometry and field emission scanning electron microscopy with energy dispersive X-ray spectroscopy to determine the role of soil components in competitive copper and cadmium migration and fixation in soils. Geoderma 2015, 251, 65-77. [CrossRef]

38. Arenas-Lago, D.; Andrade, M.L.; Lago-Vila, M.; Rodríguez-Seijo, A.; Vega, F.A. Sequential extraction of heavy metals in soils from a copper mine: Distribution in geochemical fractions. Geoderma 2014, 230, 108-118. [CrossRef]

39. Arenas-Lago, D.; Vega, F.A.; Silva, L.F.; Andrade, M.L. Copper distribution in surface and subsurface soil horizons. Environ. Sci. Pollut. Res. 2014, 21, 10997-11008. [CrossRef]

40. Loganathan, P.; Vigneswaran, S.; Kandasamy, J.; Naidu, R. Cadmium sorption and desorption in soils: A review. Crit. Rev. Environ. Sci. Technol. 2012, 42, 489-533. [CrossRef]

41. Arienzo, M.; Christen, E.W.; Quayle, W.; Kumar, A. A review of the fate of potassium in the soil-plant system after land application of wastewaters. J. Hazard. Mater. 2009, 164, 415-422. [CrossRef]

42. Armstrong, A.S.B.; Tanton, T.W. Gypsum applications to aggregated saline-Sodic clay topsoils. Eur. J. Soil Sci. 2010, 43, 249-260. [CrossRef]

43. Wang, G.; Zhang, S.; Zhong, Q.; Peijnenburg, W.J.; Vijver, M.G. Feasibility of Chinese cabbage (Brassica bara) and lettuce (Lactuca sativa) cultivation in heavily metals-contaminated soil after washing with biodegradable chelators. J. Clean. Prod. 2018, 197, 479-490. [CrossRef] 
44. Khan, Z.; Hashmi, A.A.; Ahmed, L.; Haq, M.M. Kinetics and mechanism of chromic acid oxidation of oxalic acid in absence and presence of different acid media A kinetic study. Int. J. Chem. Kinet. 1998, 30, 335-340. [CrossRef]

45. James, B.R.; Bartlett, R.J. Behavior of chromium in soils. VI. Interactions between oxidation-reduction and organic complexation. J. Environ. Qual. 1983, 12, 173-176. [CrossRef] 